\title{
Defining drama literacy - beginning the conversation
}

\author{
Madonna Stinson \\ School of Education and Professional Studies, Griffith University, Brisbane, Australia
}

For some time, I have been thinking about the concept of drama literacy and what it might mean to be drama literate. I have to admit to some discomfort about the term. Perhaps, that is because 'literacy' in the traditional English teaching sense is often reduced to the discrete teaching of the component parts of the field in isolation, e.g., phonics or grammar. In drama, this might equate to teaching the elements of drama in isolation, or the 'paint-by-numbers' approach often applied to the use of dramatic conventions within process drama. So, the term 'drama literacy' causes some ambivalence and discomfort.

However, it is frequently the case that what makes us feel uncomfortable or uncertain is the same thing that is most worth exploring. Hence, drawing on the expert knowledge in and of our field, this article begins a conversation about what drama literacy might mean.

\section{Turning to theatre literacy}

I begin with consideration of 'theatre literacy' since, one would assume, this is closely related to drama literacy. The Theatrespace research project (O'Toole et al. 2014) findings suggested that teachers, and theatre creatives, believe that theatre literacy is essential for engagement in theatre as audience, and crucial in enabling students to understand, analyse and describe the theatre experience (Burton, Bundy, and Ewing 2014). Burton et al. assure us that theatre literacy is developed and enhanced by formal study of theatre or a wide experience of theatre over time. For them, theatre literacy is demonstrated by:

- the use of technical theatre language or meta-language when identifying the 'aesthetic and conceptual' elements of a play, including the capacity to make connections between productions of both similar and unlike forms;

- the use of language of experience and pleasure, characterised by responses indicating excitement and enthusiasm for the liveness of the event;

- the capacity to compare one theatre experience with a range of other live performances; and

- active involvement in performance making. 
Table 1. Adapted from Neelands (1998), pp. 16-17.

\begin{tabular}{|c|c|c|c|}
\hline Level 1 & Level 2 & Level 3 & Level 4 \\
\hline $\begin{array}{l}\text { Public self in the social } \\
\text { setting of the classroom. } \\
\text { Student behaves as they } \\
\text { would in any social } \\
\text { situation that involved } \\
\text { their classmates. }\end{array}$ & $\begin{array}{l}\text { Public self but operates as } \\
\text { a role in the social } \\
\text { setting of the classroom. } \\
\text { Student participates and } \\
\text { recognises the fiction } \\
\text { but participates as 'self' } \\
\text { rather than } \\
\text { communicating the } \\
\text { responses of an 'other'. }\end{array}$ & $\begin{array}{l}\text { Operates as a role but } \\
\text { projects a social or } \\
\text { cultural attitude to } \\
\text { events, which is different } \\
\text { from normative or } \\
\text { habitual self. } \\
\text { Student begins to } \\
\text { imagine, how someone } \\
\text { who is different might } \\
\text { respond and behave in } \\
\text { the circumstances of the } \\
\text { drama. }\end{array}$ & $\begin{array}{l}\text { Role taken as } \\
\text { representative of a social } \\
\text { or cultural group with its } \\
\text { own history and } \\
\text { characteristic response. } \\
\text { Student researches, } \\
\text { projects and plays as a } \\
\text { role who is } \\
\text { characteristically } \\
\text { different and who has a } \\
\text { clear sense of a past and } \\
\text { a destiny. }\end{array}$ \\
\hline
\end{tabular}

They propose that young people who are theatre literate are able to talk fluently about theatre performances, using the technical vocabulary that indicates broad and deep knowledge of the art form in performance. Importantly, and in addition, they use language that conveys excitement and pleasure as they identify key moments in the experience. Theatre literate young people are capable of engaging in dialogue about specific performance elements, comparing one performance with another, and are not simply focused on the practice of 'going to the theatre'. An important finding of the Theatrespace research project was the definitive contribution made to the development of theatre literacy by active involvement in performance making. In other words, theatre literate young audience members came to be theatre literate because of their own experiences as creators of dramatic works.

To break this down, we see that theatre literacy is developed over time and experience with live theatre events, both as audience and creators of those events. Theatre literate individuals convey excitement and pleasure in theatre events and performances. They are also able to discern and talk knowledgeably about specific elements within performances, identifying key moments in the experience.

While this is a useful definition, it does not quite capture the full scope of what I would consider to be the drama literacy I strive to develop with my students of all ages from Prep onwards to tertiary education. This concern sent me to seek out other, general definitions of literacy.

\section{Literacy}

The term 'literacy' refers to descriptions of knowing that are much broader than language because human society has developed multiple meaning systems to express and communicate meanings (Bruner, 1979; Eisner 1998, 2002, 1976; Langer 1953). Saxton and Miller (2009) point to 'more than thirty recognised literacies' and firmly state that:

to be literate ... is to be able to function in the world as a participant in, contributor to, and shaper of a democratic society; to possess the critical literacies that shape us as much as they are shaped by us. (p. 35)

The notion of being able to function in, contribute to and shape the world seems to be fundamental to being someone who is literate. The definition above refers to language 
Table 2. Connecting level statements and drama literate practices.

Thread:

These threads are common across all

the arts subjects and levels.

Exploring ideas and improvise with ways to representideas.

Manipulating and applying the elements/concepts with intent.

Developing and refining understanding of skills and techniques

Structuring and organising ideas into form

Sharing artworks through performance, presentation or display.

Analysing and reflecting upon intentions.

Responding to and interpreting artworks.
Statement:

Years $7 \& 8$ Drama

Drama literate practices involve:

Combine the elements of drama in devised and scripted drama to explore and develop issues, ideas and themes.

Develop roles and characters consistent with situation, dramatic forms and performance styles to convey status, relationships and intentions.

Plan, structure and rehearse drama, exploring ways to communicate and refine dramatic meaning for theatrical effect.

Develop and refine expressive skills in voice and movement to communicate ideas and dramatic action in different performance styles and conventions, including Australian drama styles developed by Aboriginal and Torres Strait Islander dramatists.

Perform devised and scripted drama maintaining commitment to role.

Analyse how the elements of drama have been combined in devised and scripted drama to convey different forms, performance styles and dramaticmeaning.

Identify and connect specific features and purposes of drama from contemporary and past times to explore viewpoints and enrich their drama making, starting with drama in Australia and including drama of Aboriginal and Torres Strait Islander Peoples.
- Knowing and being able to apply the elements of drama in practice.

- Combining dramatic elements purposefully to create devised work which expresses and communicates issues, ideas, themes.

- Applying the elements of drama to interpretation of scripted text which explores/develops issues, ideas, themes.

- Developing and playing roles that are 'characteristically different'.

- Suiting the presentation of role/character to the form or style in which the work is created

- Showing power, status, relationship and intention through making linguistic and paralinguistic choices.

- Having the know-how to structure dramatic work in various forms and styles.

- Collaborating in rehearsal processes that are effective in refining performance work.

- Experimenting with a range of ways of communicating meaning in rehearsal to determine the best fit.

- Considering the specific audience and ways of communicating meaning.

- Developing vocal skills of breathing, breath control, articulation, projection, interpretation and modulation.

- Developing physical skills and movement to suit specific performance styles and conventions.

- Communicating ideas and dramatic action through voice and movement appropriate to a specific performance style to others (an audience) outside the dramatic action.

- Recognising selected Australian dramatic works and styles, and their conventions.

- Understanding protocols relating to the performance of selected Aboriginal and Torres Strait Islander dramatic works.

- Creating and performing devised drama.

- Interpreting and performing scripted drama.

- Maintaining integrity of role throughout the performance.

- Analysis of elements of drama within performed dramatic text.

- Considering the interplay of the elements in combination and the impact on dramatic meaning.

- Identifying forms and styles and how the elements of drama operate differently in diverse forms and styles.

- Evaluating the intentions and expression and communicating of meaning of the performed text.

- Recognising the forms and styles of a range of dramas from contemporary and past times.

- Considering drama 'texts' from a range of viewpoints (see above)

- Interpreting features and purposes, and applying these to the creation of new work.

- Knowing (experiencing as audience, reader and actor/director/dramaturg) some Australian drama, including drama of Aboriginal and Torres Strait Islander Peoples. 
literacy but could equally apply to drama literacy. More recently, Huber, Dinham, and Chalk (2015) have attempted to broaden the notion of literacy and move the definition into the twenty-first century. These authors have coined the term 'epiliteracy' and claim that epiliterate practices, 'supersede those of traditional text-based literacy' (Huber, Dinham, and Chalk 2015, p. 45).

Here is an extended quote from their article, which will resonate with drama educators:

Arts practitioners and other epiliterate individuals using new media incorporate visual, gestural, spatial and aural features in which elements (e.g., line, shape, form, value, space, colour and vector) are animated by design principles such as rhythm, balance, emphasis/ contrast, proportion, gradation, harmony/unity, variety and movement to create multimodal compositions (Callow 2013; Dinham 2014). Such compositions in both traditional arts and new multimodal contexts engage the creator and the interpreter in building personally relevant, evolving, systemic narratives in which elements within the system operate in concert with one another. (Huber, Dinham, and Chalk 2015, p. 46)

How wonderful to think of the literate individual building 'personally relevant, evolving, systemic narratives'! And this definition seems a comfortable fit since drama is essentially multimodal and multimediated.

More traditionally, we look to the Australian Curriculum where Literacy is one of the General Capabilities. The definition below is current at the time of writing:

In the Australian Curriculum, students become literate as they develop the knowledge, skills and dispositions to interpret and use language confidently for learning and communicating in and out of school and for participating effectively in society. Literacy involves students in listening to, reading, viewing, speaking, writing and creating oral, print, visual and digital texts, and using and modifying language for different purposes in a range of contexts. (ACARA 2014, p. 143)

It seems that if we combine aspects of each of the above definitions, literacy may involve the capacities to participate in, contribute to and shape society, to create and express personally relevant ideas and stories, and include skills in interpretation and communication in apt ways for diverse purposes and contexts.

Importantly, ACARA goes on to state that, 'Success in any learning area depends on being able to use the significant, identifiable and distinctive literacy that is important for learning and representative of the content of that learning area (emphasis added)'. The remainder of this article goes on to consider what might be the 'identifiable and distinctive' literacy that is representative of drama learning.

\section{Literacy in drama}

In 2014, I defined drama literacy as follows:

Drama literacy can be defined, as the capacity to 'read' and 'write' in the symbolic languages of drama, to 'know' and to know how to make and communicate meaning personally, individually and collectively in, through and about dramatic contexts. Drama literacy is in-definite because it is neither fixed nor immutable. The nature of the dramatic experience is ephemeral and transient and our capacity to understand and manage the dramatic experience grows and develops throughout our lives as makers and responders. Drama literacy cannot and should not be reduced to a list of skills or elements and 
conventions to be learnt. It comes from knowing within the whole experience rather than knowing only how to identify or apply the elements and conventions to [a particular] form, although that, of course is one aspect of drama literacy. (Stinson 2014, p. 140, emphasis added)

Drama literacy involves students knowing in drama, not only the feeling response, the embodied response that occurs moment by moment as we participate in drama learning activities, but also the know-how to form, shape, initiate and bring to a conclusion drama work of their own. They also must know how to interpret, innovatively and expressively, the created work of others, both by responding to that work as reader/ audience and by bringing new life to existing texts. Since drama is a social art form, literacy is both developed and demonstrated in collaborative and collective action. Since drama is an embodied art form, involving cognition, emotion and physical action, it is vital that the drama classroom remains an educational setting where embodied pedagogy and practice is privileged. Drama literacy is developed through learning experiences planned and implemented by qualified teachers who understand the art form (Dunn and Stinson 2011) and who implement carefully designed and structured processes of doing, making, forming, performing and responding. Our Drama literate students understand how it is to be 'other', to step into the shoes of experience of someone other than oneself. This is a pathway to human understanding and empathy. As Neelands, quoting lan McEwan from the front page of The Guardian, illustrates, 'Imagining what it is like to be someone other than yourself is at the core of our humanity. It is the essence of compassion, and it is the beginning of morality' (Neelands 2002, p. 6). As we evolve into drama literate individuals, we develop nuanced understanding of ourselves and the roles we play when alone or interacting with others, and a similarly nuanced understanding of what it might be to inhabit the world (real, historical or imagined) as someone else.

\section{Drama in the Australian curriculum}

The rationale of the Drama subject in the Australian Curriculum explains:

Drama is the expression and exploration of personal, cultural and social worlds through role and situation that engages, entertains and challenges. Students create meaning as drama makers, performers and audiences as they enjoy and analyse their own and others' stories and points of view. (ACARA 2014, p. 44)

Thus, the curriculum draws on some of the essentials of drama literacy as it aims to develop drama literacy with students.

The 'overview' of the Drama subject on the Australian Curriculum website lists what is regarded as important content for drama (see www.australiancurriculum.edu.au/thearts/drama/learning-in-drama). This content may well be considered the essential components of drama literacy, according to the curriculum as published. The overview states:

In Drama, students physically inhabit an imagined role in a situation. By being in role and responding to role, students explore behaviour in the symbolic form of dramatic storytelling and dramatic action. In purposeful play, students' exploration of role sharpens their perceptions and enables personal expression and response. Their intellectual and emotional 
capacity grows, specifically the capacity to feel and manage empathy. As audiences, students learn to critically respond to and contextualise the dramatic action and stories they view and perceive.

Creating, performing and viewing drama enables the exploration of ideas and feelings. The exploration of dramatic forms and styles, and associated cultural, social and historical contexts, diversifies students' expression, understanding and experience of their world.

What we can take from the above is that drama literacy builds up over time when students are able to access learning experiences that involve active learning while in and out of role. The nature and complexity of role and the demands of the role need to build as experience grows. Jonothan Neelands (1998) has provided some interesting analysis on role development. He has constructed a schema that describes the capacity to accept and work in role in six levels, culminating in a standard that would be equivalent to the work of a professional actor. In Table 1 I have summarised four out of the six levels he proposes for progression in the compulsory years of schooling. Neeland's Level 5 and 6, not shown here, would most likely apply to Year 11 and 12 students, and beyond into the professional field.

Here, Neelands delineates progress from playing the 'self' to being able to work within and understand the role and characteristics of an 'other', i.e., someone whose life experiences and attitudes may be very different to one's own. He goes on to explain that it is through exploring and experimenting with a range of human perspectives, especially when those perspectives are at variance to one's own that we come to understand ourselves, confront our own preconceptions, and gain a sense of the diversity and complexity of the human context (Neelands 1998). Neelands' progression is not the only way of looking at role development but is very useful when trying to plan a school program that considers what teaching and learning will allow the student to move from one level to the next, I propose that a drama literate student is aware of their own growth, and understanding of role, and would be able to identify where they sit on the progression that Neelands offers.

Obviously, there is more to drama literacy than the capacity to work in roles of varying complexity. I have suggested above that it is the capacity to 'read' and 'write' in the art form. The 'alphabet' with which we drama practitioners read and write is described in the content areas of our curriculum.

The content areas $^{1}$ that form the structure of the drama subject in the Australian curriculum are:

- The elements of drama - role, character and relationships, situation, voice and movement, space and time, focus, tension, language, ideas and dramatic meaning, mood and atmosphere and symbol. It is the dynamic interplay of the elements of drama that create dramatic meaning (Pascoe 2003, p. 31).

- Principles of narrative (story) - elements of drama are combined using contrast, juxtaposition, dramatic symbol and other devices of story.

- Viewpoints - those of playwrights, actors, directors and audiences. Meanings and interpretations are informed by personal, social, cultural and historical contexts, together with knowledge of how elements, materials, skills and processes are used. 
- Forms - form refers to the way devised and scripted drama is structured. Drama forms are shaped by the application of the elements of drama, manifested in particular dramatic conventions, and are embedded in particular social, cultural and historical contexts.

- Skills, techniques and processes - voice, movement, collaboration and teamwork, text interpretation in and for performance, devising and development of script, design and production skills and techniques, role-playing, improvising, participating in process drama, playbuilding, interpreting scripts, rehearsing and directing, and responding to drama as audience, acting, directing, scriptwriting, dramaturgy, designing, producing, managing and critical analysis.

- Materials - voices and bodies (movement, facial expression, gesture, posture) and production components (props, costumes, lighting, sound and staging equipment and performance spaces).

Each of these content areas will need to be considered when planning from the overarching curriculum framework provided by ACARA. However, progression of learning as described in the scope and sequence of the curriculum will be 'evident through the actions of students as a result of learning experiences planned and implemented by teachers' (Stinson 2008, p. 55). Progression does not happen by itself, but instead occurs as a result of participation in learning experiences and processes, either within or outside formal schooling. Individual schools and teachers will interpret, blend and synthesise the described content statements into specific developmental teaching and learning frameworks and lessons designed to meet their students' needs, interests and aspirations.

\section{Structuring learning to develop drama literacy}

I thought it might be useful, as a starting point, to take just one level from the Scope and Sequence Drama thread statements and to consider what are the literate practices that each of those statements imply (Table 2). The statements below apply to Years 7 and 8. It is important to recognise that these statements will only hold true when the curriculum has been in place for some years and students enter Year 7 having had access to the prior learning essential to allow them to meet the statements at this level. Similarly, the next stage should offer opportunities for students to work with designated drama content with more depth, complexity, control and independence.

It is exciting to think of the possibilities of working with students developing drama literacy as the new curriculum is implemented. We will need to carefully consider how we go about creating the habits of mind that promote drama literacy in and beyond the classroom; how we will provide coherent and connected and arts-rich courses of study that allow for continuous development for all students; how we will go about providing opportunities for complex and connected learning rather than fragmented and episodic events. And we need to consider how the drama literacy we develop in our classrooms connects to life experiences outside the workshop walls.

Of course, this is just the beginning of the conversation.

Note: An earlier version of this article has been published in Drama Queensland says: Mosaic. Vol 38, pp. 30-40, 2015. 


\section{Note}

1. See www.australiancurriculum.edu.au/the-arts/drama/learning-in-drama.

\section{Disclosure statement}

No potential conflict of interest was reported by the author.

\section{Notes on contributor}

Madonna Stinson is a Senior Lecturer in the School of Education and Professional Studies, Griffith University.

\section{ORCID}

Madonna Stinson (D) http://orcid.org/0000-0003-3627-6108

\section{References}

ACARA. 2014. The Australian Curriculum: The Arts Version 6.0 Dated Tuesday 18 February, 2014. Canberra: Australian Curriculum, Assessment and Reporting Authority.

Bruner, J. 1979. On Knowing: Essays for the Left Hand. Cambridge, MA: Harvard University Press.

Burton, B., P. Bundy, and R. Ewing. 2014. "Theatre Literacy." In Young Audiences, Theatre and the Cultural Conversation, Eds. J. O'Toole, R.-J. Adams, M. Anderson, B. Burton, and R. Ewing, 145158. Dordrecht: Springer.

Callow, J. 2013. The Shape of Text to Come: How Image and Text Work. Newtown. NSW: Primary English Teaching Association of Australia.

Dinham, J. 2014. Delivering Authentic Arts Education. 2nd ed. South Melbourne, Vic.: Cengage.

Dunn, J., and M. Stinson. 2011. "Not without the Art!! The Importance of Teacher Artistry When Applying Drama as Pedagogy for Additional Language Learning." RIDE: The Journal of Applied Theatre and Performance 16 (4): 617-634. doi:10.1080/13569783.2011.616395.

Eisner, E. W., Ed. 1976. The Arts, Human Development and Education. Berkeley, Cal.: McCutchan. Eisner, E. W. 1998. The Kind of Schools We Need. Portsmouth, NH: Heinemann.

Eisner, E. W. 2002. The Arts and the Creation of Mind. New Haven \& London: Yale University Press. Huber, A., J. Dinham, and B. Chalk. 2015. "Responding to the Call: Arts Methodologies Informing 21st Century Literacies." Literacy 49 (1): 45-54. doi:10.1111/lit.12054.

Langer, S. K. 1953. Feeling and Form. New York: Charles Scribner's Sons.

Neelands, J. 1998. Beginning Drama 11-14. London: David Fulton.

Neelands, J. 2002. "11/09 the Space in Our Hearts." Drama 9 (2): 4-10.

O'Toole, J., R.-J. Adams, M. Anderson, B. Burton, and R. Ewing, Eds. 2014. Young Audiences, Theatre, and the Cultural Conversation. Dordrecth. The Netherlands: Springer.

Pascoe, R. 2003. "The Language of Drama: Making and Communicating Meaning." In More than Words Can Say, edited by J. Livermore. Canberra: National Affiliation of Arts Educators.

Saxton, J., and C. Miller. 2009. "Drama: Bridging the Conversations between Our Inner Selves and the outside World." English in Australia 44 (2): 35-42.

Stinson, M. (2008). "The Shifting Sands of Curriculum Development: A case study of the development of the Year 1 to 10 The Arts Curriculum for Queensland Schools". Unpublished PhD Dissertation., Queensland:. Griffith University.

Stinson, M. 2014. "Drama Literacy: In-Definite Articles." In Literacy in the Arts, Ed. G. Barton, 131142. Switzerland: Springer. 